\title{
ACCOUNTING AND ANALYTICAL PROCUREMENT OF STATE FINANCIAL CONTROL AND DIRECTIONS OF ITS IMPLEMENTATION IN UKRAINE
}

\author{
Iryna Maksymenko', Tatyana Melikhova² \\ Zaporizhzhia National Technical University, Ukraine
}

\begin{abstract}
The growth of the constructive role of public financial control in management is a logical consequence of the modernization of the established system of state financial control and necessitates an update of the ideology and paradigmatic principles of state financial control. A retrospective review of the theoretical and practical aspects of the methodology and organization in the state financial control of Ukraine suggests that in the scientific environment these issues are studied extensively. However, despite the scientific and practical value of these works, the question of the possible modernization of the modern system of state financial control in the conditions of Ukraine's integration into the world economic system remains unresolved for the time being and is still the subject of lively discussions. The subject of the study is theoretical and methodological principles and methods for the implementation of state financial control, as well as the results of the activities of the State Audit Office of Ukraine for 2017. The purpose of the study is to substantiate the theoretical positions of the system of state financial control in Ukraine, to analyse the activity of the State Audit Service of Ukraine for 2017, and to suggest ways to improve it. To achieve the research goal, the following questions are addressed and solved: the analysis of the activity of the State Audit Service of Ukraine was carried out, based on the results of which the financial impropriety and state of its elimination for 2017 were described; the analysis revealed an increased attention to the organization of an effective system of financial control of budgetary institutions, the continuous improvement of mechanisms of management and control over budgetary funds. Method. To achieve the defined goal, a complex of general scientific and special methods was used: the method of system analysis and complex structures formalization; generalization and scientific abstraction; statistical method of data processing, grouping method. Results. However, despite the scientific and practical value of these works, the question of the possible modernization of the modern system of state financial control in the conditions of civilization and formation transformation of society through the establishment of paradigmatic principles of public audit, which are already typical of most highly developed countries of the world, remain in Ukraine today finally unresolved and still the subject of lively discussions. Conclusions. An important requirement for the construction of a modern system of state financial control at all levels of management is the implementation of control on the basis of ensuring a clear interaction and coordination of efforts of all participants in financial and budgetary relations to solve tasks of state financial control. The modern system of public financial control should be designed in such a way that it can be quickly and effectively adjusted to the solution of new challenges. Thus, only the complex realization of the measures specified in the study will provide the best effect from their introduction. In view of this, the need to improve the system of public financial control is particularly urgent and relevant. This contribution was supported by research work of the Department of Accounting and Taxing of the Zaporizhzhia National Technical University No. 0115U004682 "Transformation of accounting, analysis, and audit methods in the context of integration processes in Ukraine".
\end{abstract}

Key words: budgetary institution, budgetary funds, state financial control, State Audit Service of Ukraine, taxes.

JEL Classification: E44, E60, E69, G18, G20

\footnotetext{
Corresponding author:

${ }^{1}$ Department of Accounting and Taxing, Zaporizhzhia National Technical University.

E-mail:m.irina.y@mail.ru

${ }^{2}$ Department of Accounting, Analysis, Taxation and Audit, Zaporizhzhia State Engineering Academy.

E-mail: tanya_zp_zgia@ukr.net
} 


\section{Introduction}

One of the main problems that governments across the world are likely to face is the lack of budget resources for the state to fully fulfil its functions and to ensure the provision of constitutionally mandated civil rights. This sets a task before all the state structures, which involved in the budget process: ensuring the targeted and efficient allocation of budget funds.

The strengthening of financial control from the state for rational and efficient use of financial and material resources by budget institutions is becoming a top priority in recent years, as the number of violations in the budget sphere remains so significant that it requires continuous monitoring of the budget funds management efficiency.

The growth of the constructive role of public financial control in management is a logical consequence of the modernization of the established system of state financial control and necessitates an update of the ideology and paradigmatic principles of state financial control. A retrospective review of the theoretical and practical aspects of the methodology and organization in the state financial control of Ukraine suggests that in the scientific environment these issues are studied extensively. Particularly important in this area are the works of I. Basantsov (Basantsov, 2014: 78-81), who deals with the issues of independent external audit in the system of public administration, as well as strategic directions of modernization of state financial control; F. Butynets, in the field of view of which the economic basis for the organization and implementation of economic control and audit at enterprises of all forms of ownership; $\mathrm{O}$. Chul (Chul, 2011: 193-202), who explores the general theory of control, fundamentals of state financial control methodology and organization in Ukraine, conducts an analysis of theoretical and methodological and practical principles of the functioning of the system of state financial control in Ukraine, as well as directions of its development in conditions of economic transformations.

However, despite the scientific and practical value of these works, the question of the possible modernization of the modern system of state financial control in the conditions of civilization and formation transformation of society through the establishment of paradigmatic principles of public audit, which are already typical of most highly developed countries of the world, remain in Ukraine today finally unresolved and still the subject of lively discussions.

The objective of the research is to analyse results of the state financial control in order to increase the efficiency of using budget funds in Ukraine and ways to improve it.

\section{The economic essence of state financial control}

The main tasks of the state financial control body are: implementation of state financial control over the use and protection the state financial resources, non-current and other assets, accuracy of demand determination in budgetary funds and liabilities incurrence, effective use of funds and property, the state and reliability of accounting and financial accountability in government departments and other executive bodies, state funds, funds of statutory state social insurance, budgetary authorities and economic entities of the public sector of the economy as well as enterprises, institutions, and organizations receiving (received during the period audited) funds from budgets of all levels, state funds and funds of compulsory state social insurance, or use (used in the period audited) public or communal property, in compliance with budget laws, statutory compliance on public procurement, economic entities activities, irrespective of forms of ownership, which are not assigned by law to the controlled institutions, according to judicial decisions, adopted in criminal proceedings.

In accordance with the Law of Ukraine of 26.01.1993 No. 2939-XII "On Basic Principles of the State Financial Control Implementation in Ukraine" (as amended) and the Regulation on the State Audit Service of Ukraine, approved by the Resolution of the Cabinet of Ministers of Ukraine on February 3, 2016 No. 43, the main tasks of bodies of the State Audit Service of Ukraine are the implementation of state financial control aimed at assessing the effective, lawful, targeted, efficient use, and preservation of public financial resources and budget savings achievement.

During the implementation of the state financial control measures, there are a number of cases of excessive need for budget funds, implementation of budget expenditures, which with the Budget Code and the Law on State Budget are assigned to other levels of the budget (non-transferable proper authorisation), financing without approved budgets, etc. The implementation of such operations leads to excessive allocation of funds from budgets of all levels and, as a result, causes significant budget losses.

Thus, in the course of the state financial control implementation, the facts are established as for the overstatement the demand for budgetary funds, conducting expenditures out of public funds, which by Budget Code and the State Budget Law was taken to the budgets of another level (without the transfer of respective powers), financing without approved estimates, etc. The implementation of such operations leads to an unnecessary allocation of funds from budgets of all levels and, as a result, results in significant budget losses.

By providing state control over the use of budget funds, with the state safe of public and municipal property maintenance, the State Audit Service, within the limits of the powers granted by the legislation, during 2017 studied the main trends in the state property management and implemented transactions with state property and funds. 
This control covers such important areas for society as education, healthcare and social protection of the population, science and culture, housing and communal services, fuel and energy and agro-industrial complexes, transport, defence, etc. Control measures during the year have been carried out in accordance with quarterly work plans.

In addition, the State Audit Service's bodies conducted a number of control measures to fulfil the instructions of the Cabinet of Ministers of Ukraine, as well as at the request of law enforcement agencies.

The topics, under which control measures have been carried out in most ministries, other central executive bodies, large enterprises of the state and municipal sectors of the economy, local self-government bodies, etc., have been determined taking into account their relevance, social value, volumes of funds from the state and local budgets aimed at financing the budget programs and taking into account the risks of committing financial irregularities.

\section{Analysis of activities of the State Audit Service of Ukraine}

In order to increase the level of management of local budget resources, optimize expenditures of local budgets, and strengthen their revenue, and within the framework of strengthening control over the implementation of local budgets, by 2017, the State Audit Service provided 39 control measures on the implementation of local budgets of different levels, among which 22 are revisions and 17 - audits. With the help of these control measures, there was revealed a number of problems and disadvantages in the state resources management, numerous cases of illegal and inefficient spending of budget funds, as well as the existence of substantial reserves for filling the revenue base of local budgets were identified.

The detailed information regarding volumes of revealed and refund of such violations according to regions are presented in Table 1.

Table 1

Amounts of revealed and refund of violations when allocating budget funds by regions of Ukraine for 2017

\begin{tabular}{|c|c|c|c|c|c|c|}
\hline \multirow[t]{2}{*}{ № } & \multirow[t]{2}{*}{ Region } & \multirow{2}{*}{$\begin{array}{c}\text { A number of objects } \\
\text { where irregularities } \\
\text { are detected during } \\
\text { budgetary funds } \\
\text { appropriation }\end{array}$} & \multicolumn{2}{|c|}{$\begin{array}{l}\text { A number of detected violations } \\
\text { during budgetary funds appropriation, } \\
\text { (thousand UAH) }\end{array}$} & \multicolumn{2}{|c|}{$\begin{array}{c}\text { A number of compensated violations } \\
\text { during budgetary funds appropriation, } \\
\text { (thousand UAH) }\end{array}$} \\
\hline & & & $\begin{array}{l}\text { with state budget } \\
\text { funds }\end{array}$ & $\begin{array}{l}\text { with local budgets } \\
\text { funds }\end{array}$ & $\begin{array}{c}\text { with state budget } \\
\text { funds }\end{array}$ & $\begin{array}{c}\text { with local budgets } \\
\text { funds }\end{array}$ \\
\hline 1 & Vinnytsia oblast & 4 & 162,94 & 3408,83 & 162,94 & 3072,02 \\
\hline 2 & Volyn oblast & 7 & 4812,88 & 46,24 & 0,00 & 46,24 \\
\hline 3 & Dnipropetrovsk oblast & 1 & 4728,80 & 0,00 & 571,80 & 0,00 \\
\hline 4 & Donetsk oblast & 2 & 2633,21 & 0,00 & 511,69 & 0,00 \\
\hline 5 & Zhytomyr oblast & 8 & 4291,10 & 52,27 & 1487,61 & 0,00 \\
\hline 6 & Zakarpattia oblast & 3 & 1314,93 & 181,32 & 1314,93 & 181,32 \\
\hline 7 & Zaporizhzhia oblast & 6 & 1476,49 & 3088,66 & 1476,49 & 460,62 \\
\hline 8 & Ivano-Frankivsk oblast & 1 & 0,00 & 41,23 & 0,00 & 18,02 \\
\hline 9 & Kirovohrad oblast & 2 & 428,61 & 1406,28 & 0,00 & 1406,28 \\
\hline 10 & Luhansk oblast & 2 & 415,46 & 908,34 & 415,46 & 908,34 \\
\hline 11 & Lviv oblast & 12 & 19486,01 & 1123,90 & 1618,64 & 636,30 \\
\hline 12 & Mykolaiv oblast & 1 & 0,00 & 63,69 & 0,00 & 0,00 \\
\hline 13 & Odesa oblast & 2 & 60,16 & 150,20 & 0,00 & 134,50 \\
\hline 14 & Poltava oblast & 4 & 461,46 & 160,75 & 0,00 & 130,99 \\
\hline 15 & Rivne oblast & 7 & 601,37 & 0,00 & 587,70 & 0,00 \\
\hline 16 & Sumy oblast & 8 & 2762,32 & 0,00 & 837,20 & 0,00 \\
\hline 17 & Ternopil oblast & 8 & 577,70 & 30,00 & 109,60 & 30,00 \\
\hline 18 & Kharkiv oblast & 7 & 5517,44 & 107,12 & 66,65 & 14,28 \\
\hline 19 & Kherson oblast & 8 & 8081,52 & 7813,70 & 6717,51 & 627,05 \\
\hline 20 & Khmelnytskyi oblast & 7 & 949,92 & 171,18 & 777,29 & 91,20 \\
\hline 21 & Cherkasy oblast & 12 & 9182,24 & 3261,43 & 1217,64 & 479,99 \\
\hline 22 & Chernivtsi oblast & 4 & 691,88 & 22,09 & 19,20 & 0,00 \\
\hline 23 & Chernihiv oblast & 11 & 924,36 & 460,86 & 907,18 & 460,86 \\
\hline 24 & Kyiv oblast/ Kyiv city & 5 & 4478,11 & 372,52 & 56,84 & 0,00 \\
\hline & In totality & 133 & 74038,91 & 22870,61 & 18856,37 & 8698,01 \\
\hline & apparat SASU & 1 & 6050,00 & 0,00 & 0,00 & 0,00 \\
\hline & TOTAL: & 134 & 80088,91 & 22870,61 & 18856,37 & 8698,01 \\
\hline
\end{tabular}

Source: the author's development 
The most large-scale and widespread financial violations that resulted in the loss of resources are: - the sale of goods, works or services by economic entities (except for use, rent) free of charge or at a bargain price - almost $351.8 \mathrm{mln}$ USD;

- illegal expenses due to the payment of the inflated value of performed work and/or provided services and overstatement of the number and cost of purchased goods - 264.6 million;

- non-charging and failure to deliver (incomplete transfer) of receipts to the general and special (except for the slush fund of budgetary establishment) funds of the budget - almost $206.6 \mathrm{mln} \mathrm{UAH}$;

- non-charging and failure to deliver by the state and municipal enterprises of a part of the profit to the budget - more than $156.9 \mathrm{mln} \mathrm{UAH}$;

- illegal payments to individuals (compensation, benefits, privileges and subsidies, pensions, scholarships), including those who did not have the right to receive them or in excessive amounts - more than 148.9 million UAH;

- inappropriate expenses - almost $140.1 \mathrm{mln} \mathrm{UAH}$;

- writing-off the funds for costs/expenses without the receipt of goods, works or services or in volumes higher than their actual value - more than $138.6 \mathrm{mln} \mathrm{UAH}$;

- carrying out illegal (extra) wage payments - more than 111.7 mln UAH;

- lack of funds and property values - $80.1 \mathrm{mln} U A H$; - non-payment and/or non-application of measures on the recovery of amounts of penalties provided for by the terms of the agreement - $71.3 \mathrm{mln} \mathrm{UAH}$;

- illicit alienation of property - $68.3 \mathrm{mln} \mathrm{UAH}$;

- unreasonable covering of expenses of individuals or legal entities, including in the absence of accounts receivable - more than $58.6 \mathrm{mln} \mathrm{UAH}$;

- loss of income due to the write-off of accounts receivable - almost 55.4 mln $\mathrm{UAH}$;

- excessive allocation (receipt) of budget funds to legal entities, beneficiaries owing to an overstatement of the relevant calculations or who did not have the right to receive them - 51.4 mln $\mathrm{UAH}$;

- liquidation (destruction, disassembly) of property, conducted contrary to the legislation - more than 51.3 mln UAH;

- coverage of the estimated cost of the special fund at the expense of the general fund (without the restoration of cash fund expenditures of the general fund) - almost $46.0 \mathrm{mln}$ UAH;

- payment of contributions to state target funds for illegal sums for the remuneration of labour or for an overcharge charge rate of almost $42.7 \mathrm{mln} \mathrm{UAH}$;

- underpayment of income from the sale of free-ofcharge goods, services from business entities by budget institutions - over 29,0 mln UAH;

- overdue write-off for an accounting of intangible assets that are not available - $23.4 \mathrm{mln} \mathrm{UAH}$;

- insufficient payment, from the side of business entities, the appropriate income for the property, granted for use, rent - $22.7 \mathrm{mln} \mathrm{UAH}$;
- expenditures on charitable, sponsorship and other non-refundable assistance exceeding specified volumes or exceeding the maximum amount $-22.6 \mathrm{mln} \mathrm{UAH}$; - implementation at the expense of the budget of one level of expenditures, which in accordance with the budget law should be implemented from the budget of another level - $22.4 \mathrm{mln} \mathrm{UAH}$, etc.

The main reasons of such violations are low quality of internal control and irresponsible attitude by many budget managers and managers of enterprises, institutions and organizations.

State Audit Service provides a systemic control over the elimination of deficiencies and violations detected by control measures and completeness of requirements fulfilment of the State Service. So, in order to properly respond to violations of law enforcement authorities in 2017, over 1.4 thousand revision materials have been handed over.

Based on the results of control measures consideration during the reporting year, 669 pre-trial investigations have been initiated.

The provided data indicate the need for increased attention to the organization of an effective system of financial control of budgetary institutions, continuous improvement of the mechanisms of management and control of budgetary funds.

State financial control over compliance with budget legislation in budgetary institutions is aimed at ensuring effective and efficient management of budget funds and is carried out at all stages of the budget process by its participants in accordance with the Budget Code and other legislation, and provides [3]:

- budget funds management assessment (including conducting state financial audit);

- correctness of accounting and reliability of financial and budget reporting; achieving the savings in budget funds, their target use, efficiency and effectiveness in the activities of budget funds managers by adopting sound managerial decisions;

- conducting the analysis and evaluation of the state of financial and economic activity of budget funds managers;

- preventing violations of budget legislation and ensuring the interests of the state in the process of managing state-owned objects;

- substantiation of the planning of budget revenues and expenditures.

Thanks to the measures taken during 2017, the State Audit Service and its territorial bodies have provided compensation for losses of financial and material resources for a total amount of more than $611.5 \mathrm{mln}$ UAH. So, budgets and budget institutions, organizations and enterprises received almost $141.3 \mathrm{mln} \mathrm{UAH}$, as well as reimbursement and renewal of illegal, misplaced expenditures and a shortage of resources for the total amount of more than 470.2 mln UAH.

In particular: 
- held by the executors of additional works, provided services or delivered goods more than on $77.0 \mathrm{mln}$ $\mathrm{UAH}$;

- carried out netting of costs and adjustments of settlements totalling $33.1 \mathrm{mln} \mathrm{UAH}$;

- offset by a special fund the illegal expenditures made from the general fund estimates institution, organization (was to be made in the special fund) - with over 18.0 mln UAH;

- reduced budget allocations/allocations to budget funds administrators (including independently by the control bodies of control objects during the audit) for violations of excessive allocation of budget funds - in the amount of almost $30.5 \mathrm{mln} \mathrm{UAH}$ and for violations of misuse of budget funds - over $45.1 \mathrm{mln} \mathrm{UAH}$;

- adjusted payments with state social insurance funds (including credited to future payments) - by $19.3 \mathrm{mln}$ $\mathrm{UAH}$;

- returned funds to the accounts of the enterprise, institution or organization of state and communal ownership - more than 31.6 mln UAH;

- funds returned to local budgets (except for the special fund of budgetary institutions) - $68.3 \mathrm{mln} \mathrm{UAH}$, as well as returned to the state budget (except for the special fund of budget institutions) - $25.2 \mathrm{mln} \mathrm{UAH}$;

- excessively paid salaries from persons who received them unreasonably (superfluously) on their applications were kept - almost 17.6 mln UAH;

- returned illegally alienated property of state and communal property - by almost $6.0 \mathrm{mln} \mathrm{UAH}$;

- recovered funds from the guilty persons (including overdue paychecks) were collected - almost $14.1 \mathrm{mln}$ $\mathrm{UAH}$;

- returned material assets (in the amount of shortage) almost 6.8 mln UAH;

- received additional revenues to local budgets (except for the special fund of budget institutions) for the amount of more than $62.7 \mathrm{mln} \mathrm{UAH}$;

- received incomes to the accounts of enterprises (institutions, organizations) of the state form of ownership - almost $24.3 \mathrm{mln} \mathrm{UAH}$ and communal ownership - more than $6.2 \mathrm{mln} \mathrm{UAH}$;

- received incomes to the special fund of budgetary institutions and organizations financed from the state budget - more than $5.1 \mathrm{mln} \mathrm{UAH}$, and also financed from local budgets - almost 8.4 mln UAH;

- received revenues to the state budget (except for the special fund of budget institutions) - $16.2 \mathrm{mln} \mathrm{UAH}$ and so on.

In particular, during January-December 2017, the State Audit Service provided state and local budgets with the funds set forth in the Resolution of the Cabinet of Ministers of Ukraine dated February 16, 2011 No. 106 "Some Issues for Taxes, Duties, Payments and Other Budget Revenues Accounting" (with amendments) by codes of budget classification in the aggregate in the amount of more than $87.5 \mathrm{mln}$
$\mathrm{UAH}$, which is $9.3 \%$ higher than the corresponding data for 2015.

In its turn, filling the state and local budgets according to the results of control measures of the State Audit Service for the codes of the budget classification of incomes, the control over the proceeds for which have not been fixed for the State Audit Service in accordance with the Resolution number 106, in 2016 amounted to a total of more than $41.9 \mathrm{mln} \mathrm{UAH}$, the share of which or more than $95 \%$ - revenues to local budgets.

In addition to this, the State Audit Service bodies are taking other measures on the part of the materials of control measures implementation.

Thus, according to the results of the analysis of public procurement (without access to the object of control by means of a request for documents), the bodies of the State Audit Service for the reporting period prevented violations in the field of public procurement for a total amount of 4.7 bln UAH, of which abolished competitive bidding for a total of 3.8 bln UAH and contracts concluded amounting to $889.9 \mathrm{mln}$ UAH have been cancelled.

Also, within the framework of carrying out an operational audit of economic entities of the state sector of the economy, as a result of the proper response of control objects to reservations of state auditors during January-December 2016, illegal and inefficient spending of state resources was forbidden against the total amount of $275.9 \mathrm{mln} \mathrm{UAH}$.

The authorities of State Audit Service pay a considerable attention to the personal responsibility of officials who violate the financial-budgetary discipline (Harasym, Loboda, 2013).

In 2017, for breach of financial discipline for administrative responsibility (articles 164-2, 166-6, 16412 and 164-14) as a whole there were attracted more than 5.4 million public officials for the total amount of administrative fines of more than $1.8 \mathrm{mln} \mathrm{UAH}$.

To disciplinary action in the reporting period, there have been attracted 1081 officials, of which 134 is dismissed, to the material -771 persons.

In order to induce control objects to fulfil requirements for the compensation of identified losses of financial and material resources, the State Audit Service has brought to court in the interests of the state 143 lawsuits in the amount of more than $62.2 \mathrm{mln}$ UAH. In addition, 376 civil actions were initiated before the prosecutor's office, the object of control or its governing body, and another state body.

During 2017, the State Audit Service provided almost 1.7 thousand opinions and suggestions on the application of financial sanctions. In whole, according to the results of the control measures, in 139 cases budget allocations were suspended, in 1194 - operations with budget funds were stopped, and 114 budget administrators were reduced budget allocations for almost $30.3 \mathrm{mln}$ UAH. 


\section{Ways to improve public financial control in Ukraine}

The proper interaction between the bodies of the State Audit Service and the bodies of the State Financial Inspectorate is one of the factors on which the effectiveness of the tasks and functions entrusted to the bodies of the State Auditor Services on the provision of an adequate level of fiscal discipline in the context of taxes payment in the state.

Taking into account the abovementioned facts, the issue of its improvement is under constant control of the State Service. Representatives of the SASU bodies are constantly involved in conducting joint actions with the bodies of the State Financial Inspection aimed at identifying and stopping abuses and violations in the financial and economic sphere of the state, including the budgetary field.

The functioning of an efficient, high-quality, and transparent system of state financial control significantly increases the level of trust in the state both its own citizens and the foreign community, as well as creates the necessary conditions for the business development, economic growth of the country, the formation of a congenial investment climate, etc.

Key requirements to be met by the system of public financial control are presented in Fig. 1.

During the study of the contemporary trends in the state financial control at the government and local levels, it was determined that in the system of state financial control these requirements are often defied and ignored, leading to disadvantages of this system (Table 2).

As a result of the conducted research, we consider that in order to improve the state financial control, increase the level of efficiency of its implementation should be ensured: - development of common conceptual foundations of the organization of state financial control, standardization of forms and methods of control activities;

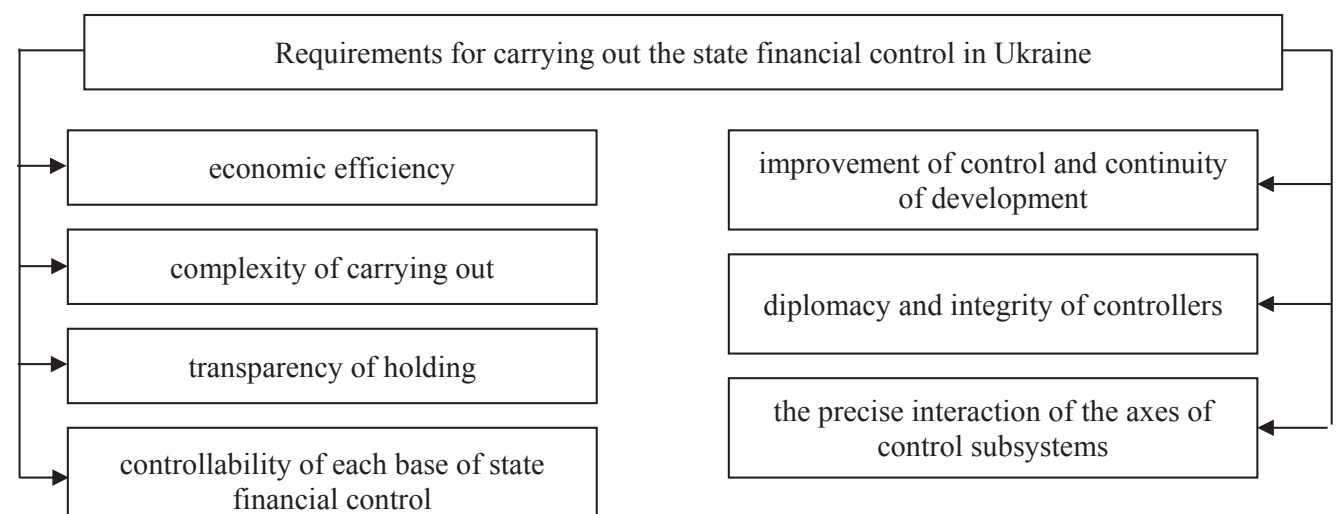

Fig. 1. Key requirements to be met by the state financial control in Ukraine

Source: the author's development

Table 2

Disadvantages of the system of state financial control in Ukraine

\begin{tabular}{|l|l|}
\hline \multicolumn{1}{|c|}{ Disadvantages of a legal status } & \multicolumn{1}{c|}{ Organizational deficiencies } \\
\hline $\begin{array}{l}\text { Lack of legislative decisions on the formation of a holistic system } \\
\text { of state financial control. }\end{array}$ & $\begin{array}{l}\text { Insufficient attention to control actions that provide preventive control } \\
\text { functions. }\end{array}$ \\
\hline $\begin{array}{l}\text { The discrepancy between the rules of existing laws and } \\
\text { regulations in the field of state financial control. }\end{array}$ & $\begin{array}{l}\text { Duplication and parallelism in the work of regulatory authority of } \\
\text { different levels, excessive overload of some objects by audits and } \\
\text { inspections. }\end{array}$ \\
\hline $\begin{array}{l}\text { Non-execution of provisions of the current legislation in terms } \\
\text { of ensuring proper interaction between the state financial control } \\
\text { authorities, which increases duplication and parallelism in the work. }\end{array}$ & $\begin{array}{l}\text { The remoteness of bodies of the state financial service from the } \\
\text { development, discussion, and adoption of organisational and legal } \\
\text { measures to prevent violations. }\end{array}$ \\
\hline \multirow{4}{*}{$\begin{array}{l}\text { Non-observance and violation of norms and principles of budget } \\
\text { and tax legislation by participants in financial and economic } \\
\text { relations. }\end{array}$} & $\begin{array}{l}\text { Insufficient explanatory work with the community on the tasks of } \\
\text { state financial control and on ensuring the elimination of committed } \\
\text { violations; uncertainty in all spheres of state financial control. }\end{array}$ \\
\cline { 2 - 3 } & $\begin{array}{l}\text { Inadequate use in the control-and-auditing methods oriented to the } \\
\text { determination of the effectiveness of the use of public financial resources. }\end{array}$ \\
\cline { 2 - 2 } & Ineffective management of public funds and property \\
\cline { 2 - 3 } & $\begin{array}{l}\text { Lack of proper responsibility of officials for the violation of laws, rules, } \\
\text { regulations and appropriate compensation of the lost resources. }\end{array}$ \\
\hline
\end{tabular}

Source: the author's development 
- adoption of standards for the implementation of state financial control to create an effective mechanism to resist violations and excessive use of law in the sphere of use of budgetary funds, as well state and municipal property;

- optimization of the organizational structure, clarification and delineation of the functions of the state financial control bodies;

- compliance with international principles of financial control at the state and regional levels, adaptation of the system of state financial control to European requirements;

- introduction of preventive forms of state financial control in the work of controlling entities;

- staffing improvement of the system of state financial control (preparation of material-and-technical, scientific and information-analytical support for system functioning of state financial control.

\section{Discussion}

Analysing the results, it should be noted that the system of public financial control in Ukraine has a number of problems and disadvantages that make it ineffective, costly and opaque. Currently, there is not enough legal, informational, organizational, communicative, methodological, and personnel support for the implementation of state financial control. All these factors have a negative impact on the level of public confidence in the government, on the development of financial and budgetary relations in Ukraine, inhibiting a number of transformations in this area. In view of this, the necessity to improve the system of state financial control is particularly relevant and urgent.

It is possible to solve the problems and overcome the weaknesses in the organization and functioning of state financial control in Ukraine through the consistent implementation of measures aimed at constructing a modern model of state financial control that would meet the needs of the national economy and the requirements of the European Union.

\section{Conclusions}

Consequently, the state financial control over accounting in budgetary institutions should be considered as a multi-faceted and complex system of checking the legality, timeliness and completeness of the formation of items of income and expenditure, the targeted use of budget funds for the relevant items of expenditure, as well as the analysis of rational and their effective use.

In particular, the state financial control should ensure proper (economic, effective, efficient, and transparent) public finance management.

That is, state financial control is an integral part of budget institutions stimulus spending and is intended to ensure the process of creating reliable information on the state of accumulation and use of budgetary funds, as well as the effectiveness of fiscal regulation to take timely and appropriate measures.

To date, in Ukraine, the following types of statefinancial control of budgetary institutions are used: financial and economic audit, state purchases and budget institutions inspection. The introduction of these types of financial control, taking into account the Standards for State Audit of Public Finances, contributed to increasing the efficiency of using budget funds. However, this analysis allowed revealing the main problems in the field of state financial control of budgetary institutions, which are the reason for a rather high level of violations of legislation. In order to increase the effectiveness of the state financial control of budgetary institutions, it is necessary, first of all, at the legislative level: to unite in a single system financial audit, checking the state purchases and budget institutions inspection; to develop a methodology for the above control measures implementation; to develop and implement a methodology for determining and assessing the risks of financial and economic activity of budgetary institutions in accordance with the fields of activity. Solving these issues will reduce violations in the financial and budgetary sphere, improve the management of financial, material and labour resources of budget institutions, as well as fulfil their functions and tasks to achieve socially important goals for society.

\section{References:}

Basantsov, I. V. (2014). Modernizatsiya systemy derzhavnoho finansovoho kontrolyu v Ukrayini [Modernization of state financial control in Ukraine]. Ekonomichnyj chasopys - XXI, vol. 1-2 (1), pp. 78-81.

Barilari, A. (2003). Les controles financiers comptables, administratifs et juridictionnels des finances publiques, Paris.

Bovens, Ed. Goodins R. Schillemans, Th. (2014), The Oxford Handbook Public Accountability, Oxford University Press, Oxford, [Online]. Retrieved from: http:// fdslive.oup.com/www.oup.com/academic/pdf/13/ 9780199641253_chapter1.pdf

Chul O. (2011). The system of state financial control: functionProblems, Optimization.Economic space. pp. $193-202$. Harasym, P., Loboda, N. (2013). Derzhavnyy finansovyy kontrol yak paradyhma natsionalnoho menedzhmentu [State financial control as a paradigm of national management]. Mechanisms of public administration (electronic journal). Retrieved from: http://www.sophus.at.ua/publ/...paradigma.../40-1-0-773 (Accessed 21 May 2016).

Kholoshyn, M. (2015). Vyshchym orhanom audytu publichnykh finansiv maye staty Rakhunkova palata [The supreme body of the audit of public finances should be a Accounting Chamber]. Matthew Holoshina's blog (electronic journal). Retrieved from: blogs.lb.ua/.../297382_vishchim_organom_auditu_public. 
Pikhotskyj, V. (2015). Systema derzhavnoho finansovoho kontrolyu v Ukrayini: kontseptual'ni zasady teoriyi ta praktyk [The system of state financial control in Ukraine: conceptual bases of the theory and practice] (PhD Thesis), Lviv: Lviv Ivan Franko National University.

Shevchenko, N. (2010). Reform of the state financial systemControl in Ukraine: Problems and Prospects. Journal of the Ukrainian Academy of Banking, pp. 42-45.

Shevchuk, O., Kopotiienko T. (2013). Reformuvannya orhaniv derzhavnoho finansovoho kontrolyu Ukrayiny $\mathrm{v}$ umovakh yevrointehratsiyi [Reform of state financial control in terms of European integration of Ukraine]. Ekonomichnyj chasopys - XXI, vol. 5-6 (1), pp. 53.

Resolution adopted by the General Assembly № 69/228 (2014). Promoting and fostering the efficiency, accountability, effectiveness and transparency of public administration by strengthening supreme audit institutions. Retrieved from: http://www.un.org/es/comun/ docs/index.asp?symbol=A/RES/69/228\&referer=/ spanish/\&Lang=E (Accessed 30 december 2017).

The Lima Declaration (ISSAI 1) (1977). Approved at IXth Congress of INTOSAI, Lima/Peru, "INTOSAI Professional Standards Committee". Retrieved from: http://www.issai.org/media/12901/issai_1_e.pdf(Accessed 30 december 2017). 